\title{
ИНЕРТНЫЕ ГАЗЫ В ГАЗОВЫХ ЗАЛЕЖАХ ЭСТОНИИ
}

На побережье Балтийского моря и на его островах издавна известны проявления углеводородного газа; делались попытки практического его использования. Впервые упоминания о газопроявлениях встречаются в работах Ф. Шмидта (Миквитц, Шмидт, 1903) и Б. Досса (Doss, 1900), сведения о газовых скоплениях приводятся в трудах А. Палена (Pahlen, 1913), Д. Бартельса (Bartels, 1929), И. Краснова (1935), А. Шуфертова (цит. по Ургард, 1966) и других исследователей.

Долгое время обсуждался вопрос о стратиграфической приуроченности и происхождении этих газов; в последнее время господствующим стало мнение, что они образовались в результате преобразования органики межморенных антропогеновых отложений, в которых они и залегают.

Определенный научный интерес представляют инертные газы в газовых залежах Прибалтики. Известно, что ряд исследователей (Козлов, Осипов, Шуфертов) указывает на высокое, до $1 \%$, содержание в газах гелия. Простота геологического строения и ясность генезиса углеводородных газов делают эти залежи хорошим объектом для проверки модели распределения гелия, концентрации которого в подземных флюндах создаются при значительном содействии пород фундамента, залегающнх здесь на небольшой глубине.

Наиболее детально изучены газопроявления на небольшом острове Суур-Прангли, находящемся у берегов Эстонии, на котором в разлнчные годы было пробурено несколько скважин. Из них последние -- в начале шестидесятых годов, с целью оценки запасов газа. В результате выявлено два основных газоносных пласта, развитых почти по всей площади острова и приуроченных к межморенным антропогеновым пескам. Запасы газа оказались недостаточными для промышленной разработки. K сожалению, опробование газовых скоплений пронзведено не качественно: многие параметры не определялись вовсе или определялись приблизительно. Так, не определялись точно глубины залегания продуктивных горизонтов, не замерялось пластовое давление.

Геологическое строение острова несложно: в основанни на глубине 128-135 м залегают граниты кристаллического фундамента, покрытые на юге острова 25-метровой толщей гдовских песчаников. Все вышележащие отложения представлены озерными, ледниковыми и морскими антропогеновыми породами. Предположение, что газопроизводящимн породами являются богатые органикой ленточные глины (Краснов, 1935), подтверждено работами Управления геологии СМ ЭССР.

Для сравнения с составом газа из межморенных отложений Ленинградской области в табл. 1 приводится состав газа из различных скважин сстрова, а также средний состав газовой залежи. В ряде сква- 
таблица

Состав газовых залежей о. Суур-Прангли

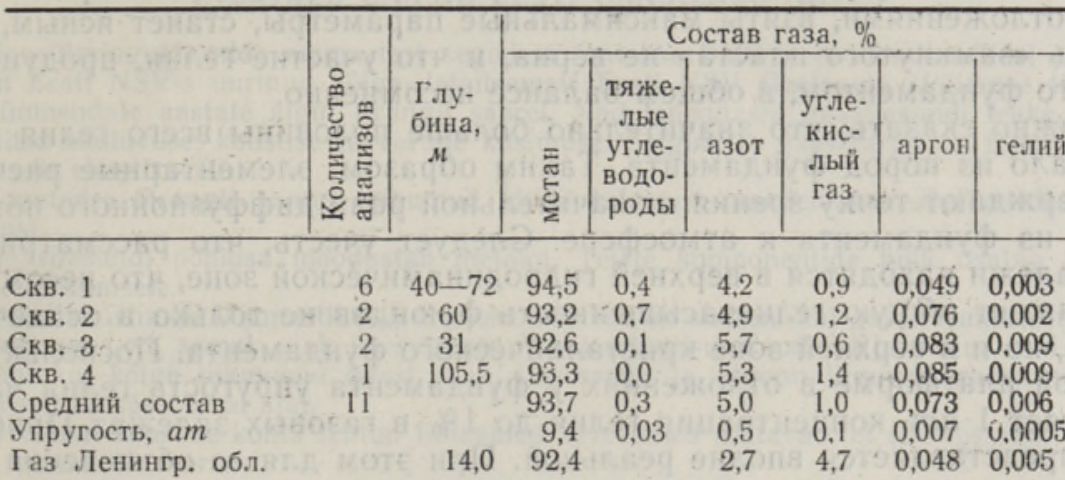

жин острова опробован спонтанный газ. Относительное постоянство концентраций аргона в подземных водах позволяет оценить газовый фактор з содержание газовых компонентов в объеме воды. Рассчитана также упругость инертных газов в воде (табл. 2).

Таблица 2

Концентрация и упругость инертных газов в пластовых водах о. Суур-Прангли

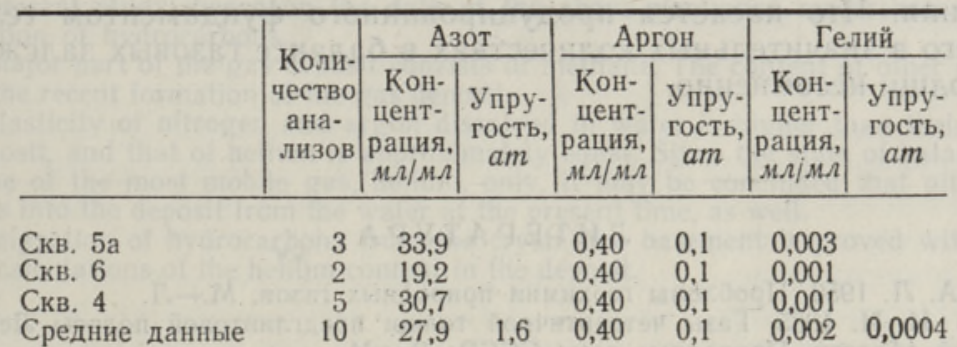

Основную часть газовой залежи составляют углеводороды, представленные почти одним метаном. Содержание других компонентов характерно для недавно образовавшихся газовых скоплений. Упругость азота и аргона в воде выше, чем упругость в газовой залежи, а у гелия - они лримерно равны. Очевидно, что при образовании углеводородного газа в свободную газовую фазу переходят как азот, аргон, так и гелий, но. равновесное состояние, видимо, установилось только для наиболее подвижного гелия, а азот и аргон переходят в газовую залежь. Это подzверждает предположение о позднем образовании газовой залежи и свидетельствуег о том, что источником азота, аргона и гелия в газе являются пластовые воды, в которых они растворены.

Известно, что гелий является продуктом радиоактивного распада. Существует мнение, что подземные флюиды насыщаются также и тем гелием, который прсдуцируется фундаментом. В связи с этим интересно оценить, в какой степени гелий, находящийся в газовом скоплении, может быть продуктом только вмещающих антропогеновых отложений. Был произведен расчет, который показал, что песчаные отложения, вмещающие газ, способны образовать в течение всего антропогенового периода лишь $1,25 \%$, а все антропогеновые отложения острова $25 \%$ наблю- 
даемого в настоящее время количества гелия в газовых залежах. Если учєсть, что для расчета количества гелия, произведенного антропогеновыми отложениями, взяты максимальные параметры, станет ясным, что модель «замкнутого пласта» не верна, и что участие гелия, продуцированного фундаментом, в общем балансе несомненно.

Можно сказать, что значительно больше половины всего гелия мигрировало из пород фундамента. Таким образом, элементарные расчеты подтверждают точку зрения о значительной роли диффузионного потока гелия из фундамента к атмосфере. Следует учесть, что рассматриваемые залежи находятся в верхней гидродинамической зоне, что несомненно снижает общую гелиенасыщенность флюидов не только в осадочной толще, но и в верхней зоне кристаллического фундамента. Поскольку на Русской платформе в отложениях у фундамента упругость гелия часто достигает $1 \mathrm{am}$, концентрация гелия до $1 \%$ в газовых залежах Прибалтики представляется вполне реальной. При этом для ее объяснения нет необходимости прибегать к поискам отложений с аномальным содержанием радиоактивных элементов.

Таким образом, анализ концентраций инертных газов подтверждае] недавнее образование углеводородных залежей в антропогеновых отложениях. Эти залежи распространены довольно широко в Эстонии, Ленинградской области и сопредельных районах и обладают сходным составом. Незначительность запасов не позволяет использовать их практически, однако изучение в легко доступных условиях процессов образования углеводородов, пронсходивших совсем недавно, а возможно происходящих и сейчас, можег значительно обогатить теорию углеводородообразования. Что касается продуцированного фундаментом гелия, го участие его в значительных количествах в балансе газовых залєжей осадочной толщи несомненно.

\section{ЛИТЕРАТУР А}

Коз лов А. Л. 1950. Проблемы геохимии природных газов. М.-Л.

К раснов И. И. 1935, Газы четвертичной толщи предглинтовой полосы Ленинградской области. Природные газы СССР, Л.-М.

Миквитц А. Ю., Ш ми д Ф. Б. 1903. О выделении горючего газа из буровой скважины на острове Кокшере. Зап. Петерб. минер. об-ва, Сер. II, ч. 41.

О си по в Ю. Т., Я нишкий И. Н. 1966. Некоторые особенности формирования зон регионального гелиенасыщения. Геохимия, № 1.

У рга рд Р. О. 1966. Гидрогеологическая изученность. В кн.: Гидрогеология СССР, $\mathrm{XXX}, 16$.

B a rte ls D. 1929. Uber ein Helium-Vorkommen in den Ostseeprovinzen. Intern. Z. Bohitechnik, Erdöl, Bergbau und Geol. No. 15, 16.

Doss B. 1900. Uber die Möglichkeit der Erbohrung von Naphthalagerstätten bei Schmarden in Kurland. Korresp.-Blatt Naturforsch. Vereins, Riga, Bd. 43.

P a h 1 e n A. 1913. Sitzungsber. Naturforsch. Gesellsch. Dorpat.

Всесоюзный нефтяной научно-исследовательский геолого-разведочный институт

Управление геологии

Совета Министров Эстонской ССР
Поступила в редакцию 2/IV 1969 


\section{INERTSED GAASID EESTI GAASILASUNDITES}

Gaasiilminguid, mida ammustest aegadest tuntakse Balti mere rannikualadel ja saartel, on Eesti NSV-s uurinud kōige detailsemalt Eesti NSV Geoloogia Valitsuse töötajad kuuekümnendate aastate algul Prangli saarel. Nad lahendasid gaasilasundi tekke, stratigraafilise kuuluvuse, koostise ja varude küsimuse. Selgus, et gaasivarud on tööstuslikuks tootmiseks ebapiisavad.

Kasutades Prangli saarel toimunud tööde tulemusi, vaadeldakse süsivesinike tekke küsimust.

Gaasilasundi pōhiosa moodustab metaan. Teiste komponentide hulk osutab lasundi hilisele tekkimisele.

Vees lahustunud lämmastiku ja argooni elastsus on suurem kui gaasilasundis, heeliumi elastsus aga on samal ajal ühesugune. Tasakaaluseisund on vâlja kujunenud ainult heeliumi kui kōige liikuvama gaasi osas, lämmastik ja argoon liiguvad gaasilasundisse nähtavasti ka käesoleval ajal.

Heeliumi koostise kohta tehtud lihtsamad arvestused näitavad, et süsivęsinike migratsioon toimub aluskorrast.

\section{A. VORONOV, E. CHEUSSOVA}

\section{INERT GASES IN THE GAS DEPOSITS OF ESTONIA}

The deposits of gas, whose existence on the coasts and islands of the Baltic was stated already long ago, were studied in greatest detail on the Isle of Prangli, Soviet Estonia, by the research workers of the Department of Geology of the Council of Ministers of the Estonian SSR, at the beginning of the 1960-ies.

The task of the studies was the solution of problems of the genesis, stratigraphic division, composition, and reserves of gas.

The present study, based on the data of the above-mentioned researches, deals with the formation of hydrocarbons.

The major part of the gas deposit consists of methane. The content of other component points to the recent formation of the gas deposit.

The elasticity of nitrogen and argon dissolved in water is higher than their elasticity in the deposit, and that of helium is approximately equal. Since the state of balance occurs in the case of the most mobile gas, helium, only, it may be concluded that nitrogen and argon pass into the deposit from the water at the present time, as well.

The migration of hydrocarbons from the crystalline basement is proved with the help of simple calculations of the helitim content in the deposit. 